\title{
ПОСЯГАТЕЛЬСТВА КОРРУПЦИОННОЙ НАПРАВЛЕННОСТИ В СФЕРЕ ОБЕСПЕЧЕНИЯ ДОРОЖНОГО ДВИЖЕНИЯ И ЭКСПЛУАТАЦИИ ТРАНСПОРТНЫХ СРЕДСТВ
}

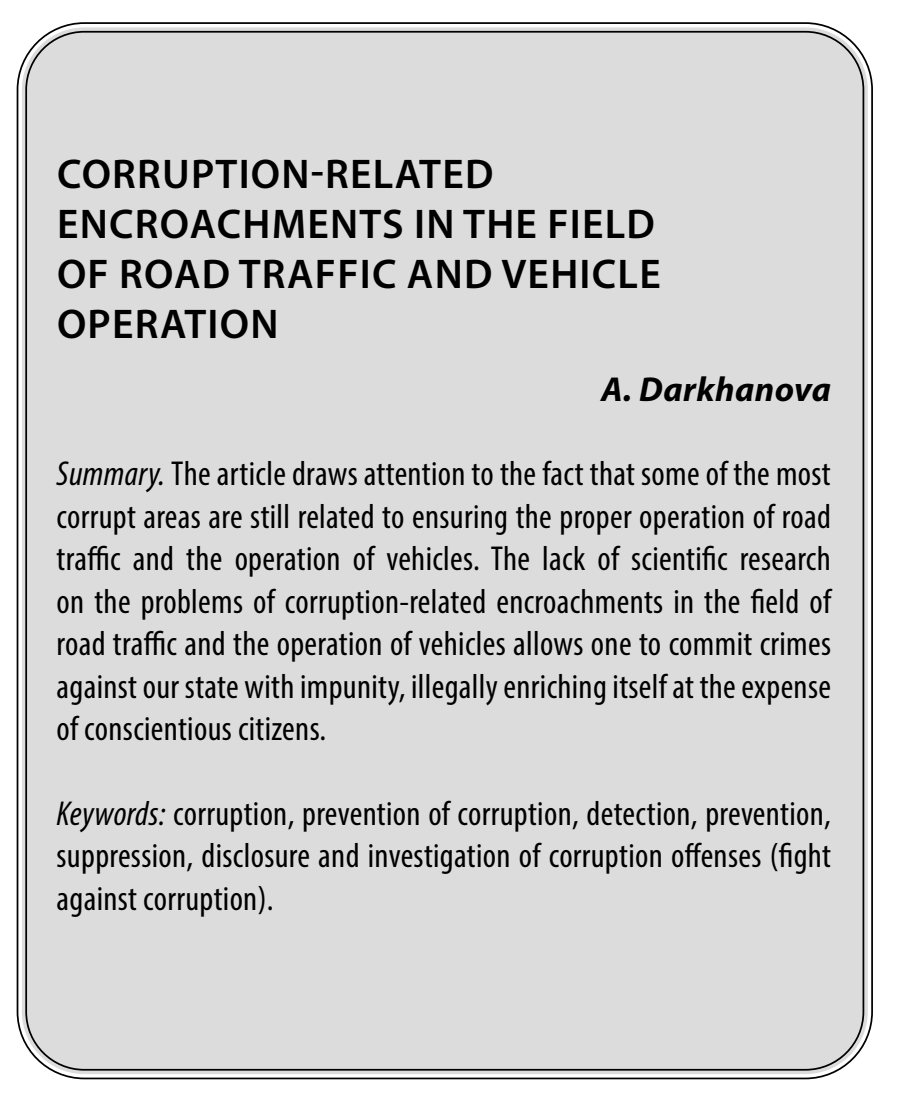

$\mathbf{K}$ оррупция превратилась в транснациональное явление, которое затрагивает все страны. Этим обусловлено исключительно важное значение международного сотрудничества в области предупреждения коррупции и борьбы с ней. В Российской Федерации коррупция имеет, пожалуй, своеобразную, присущую, вероятно, только нашей стране историю. Во многом это связано с когда-то возведенным в ранг фактически узаконенного на государственном уровне «кормления». Как известно, оно предполагало, что княжеская администрация взамен жалованья получала подношения от местного населения в течение всего периода службы[4]. В связи, с чем справедливо отмечается, что «... одной из основных причин расцвета и жизнестойкости коррупционных проявлений в нашей стране является российский менталитет. Менталитет, что складывался сотнями лет. Сегодня россияне, за некоторым исключением, считают своим долгом отблагодарить людей, что оказывают им те или иные услуги» [5, c.53-55].

\author{
Дарханова Арюна Баировна \\ Старший преподаватель, Восточно-Сибирский \\ государственный университет технологий \\ и управления \\ sanaryuna@yandex.ru
}

Аннотация. В статье обращается внимание на то, что одними из наиболее коррумпированных остаются сферы, связанные обеспечением надлежащей работы дорожного движения и эксплуатации транспортных средств. Отсутствие научных исследований по проблемам посягательств коррупционной направленности в сфере обеспечения дорожного движения и эксплуатации транспортных средств позволяют безнаказанно совершать преступления против нашего государства, незаконно обогащаясь за счет добросовестных граждан.

Ключевые слова: коррупция, профилактика коррупции, выявления, предупреждения, пресечения, раскрытия и расследования коррупционных правонарушений (борьба с коррупцией).
Вероятно, большая часть российских граждан и иных лиц, проживающих на территории страны, безусловно, осознают развернувшуюся в последние годы активную пропаганду, направленную на формирование устойчивого неприятия коррупционным проявлениям. Не проходит и дня, чтобы в средствах массовой информации не упоминали о профилактике коррупционных проявлений, не доводили до сведения широких слоев населения факты привлечения к дисциплинарной, административной и уголовной ответственности за взяточничество. На рекламных щитах, буклетах, постерах в общественном транспорте, в просветительских социальных роликах, в органах государственной власти и местного самоуправления активно распространяется информация о недопустимости коррупционного поведения.

Стоить отметить, что нарастающими темпами борьба с обозначенным негативным социальным явлением началась в России с момента ратификации в 2006 году 
Конвенции ООН против коррупции, которая одобрена Генеральной Ассамблей ООН 31 октября 2003 года и вступила в силу 14 декабря 2005 года [3] и вступления в силу Федерального закона от 25.12.2008 № 273-Ф3 «О противодействии коррупции» [1]. Названный закон является одним из ключевых в анализируемом направлении, в нем достаточно системно определяются основные направления противодействия обозначенному негативному социальному явлению. Так, всем федеральным органам государственной власти, органам государственной власти субъектов РФ, органам местного самоуправления, институтам гражданского общества, организациям и физическим лицам в пределах их полномочий предписывается противодействовать коррупции путем:

а) предупреждения, в том числе выявлением и последующем устранением причин коррупции (профилактика коррупции);

б) выявления, предупреждения, пресечения, раскрытия и расследования коррупционных правонарушений (борьба с коррупцией);

в) минимизации и (или) ликвидации последствий коррупционных правонарушений.

Множество изменений в части упреждающих мероприятий коррупционного характера внесено в большое число нормативных актов: Федеральный закон «О государственной гражданской службе Российской Федерации»; Гражданский кодекс Российской Федерации; Трудовой кодекс Российской Федерации; Кодекс Российской Федерации от административных правонарушениях и многих других.

Уголовный кодекс Российской Федерации (далее по тексту - УК РФ) за последние годы был дополнен целым рядом новых норм, предусматривающих ответственность за посредничество во взяточничестве (ст. 291.1 УК РФ), мелкое взяточничество (ст. 291.2 УК РФ), посредничество в коммерческом подкупе (ст. 204.1 УК РФ), мелкий коммерческий подкуп (ст. 204.2 УК РФ), злоупотребления в сфере закупок товаров, работ, услуг для обеспечения государственных или муниципальных нужд (ст. 200.4 УК РФ), подкуп работника контрактной службы, контрактного управляющего, члена комиссии по осуществлению закупок (ст. 200.5 УК РФ) и др.

Однако, несмотря на активные и последовательные усилия руководства страны в сфере борьбы с коррупцией вряд ли можно говорить о больших достижениях в этом направлении. Следует констатировать, что одними из наиболее коррумпированных остаются сферы, связанные обеспечением надлежащей работы дорожного движения и эксплуатации транспортных средств. Наиболее типичными в этом смысле являются, как минимум: следующие виды и способы преступных посягательств:
- взяточничество за получение в обход установленных правил документов, необходимых для управления транспортным средством, когда к примеру, государственный инспектор безопасности дорожного движения межрайонного регистрационно-экзаменационного отдела использует свои должностные полномочия вопреки интересам службы путем получения через посредников взяток в виде денежных средств за незаконные действия, входящие в его должностные полномочия, такие как, выставление положительных экзаменационных оценок при сдаче кандидатами в водители теоретических и практических экзаменов по вождению[10];

- за не привлечение к административной и уголовной ответственности за нарушения правил дорожного движения и эксплуатации транспортных средств и др., в этом смысле типично, когда сотрудником дорожно-патрульной службы за совершение в пользу водителя транспортного средства незаконного бездействия по освобождению от уголовной ответственности за управление автомобилем в состоянии алкогольного опьянения, будучи ранее подвергнутым административному наказанию за управление транспортным средством в состоянии алкогольного опьянения[9];

- превышение должностных полномочий, злоупотребление должностными полномочиями с целью незаконного привлечения к ответственности за мнимые нарушения (либо, наоборот не привлечение к ответственности) в рассматриваемой сфере и смежные правонарушения и преступления и пр. Типичным в этом смысле является пример, когда инспектор дорожно-патрульной службы вымогает взятку у водителя, управляющего транспортным средством в состоянии алкогольного опьянения. В ходе проверки документов, инспектор ГИБДД установил, что имеются признаки алкогольного опьянения, возникает преступный умысел на совершение незаконного бездействия с использованием своих служебных полномочий в пользу взяткодателя, в свою очередь не проводит освидетельствование для определения наличия в организме алкоголя, не направляет на медицинское освидетельствование на состояние алкогольного опьянения и не составляет протокол об административном правонарушении[7];

- служебный подлог. Например, внесение в официальные документы ложные сведения об обстоятельствах дорожно-транспортного происшествия. На основании данных документов впоследствии незаконного получения страхового возмещения по страховому полису ОСАГО[8]; 
- халатность. К примеру, инспектором по исполнению административного законодательства отдела ГИБДД, вследствие недобросовестного и небрежного отношения к службе в нарушение закона и должностной инструкции не обеспечил направление материалов дел об административных правонарушениях уполномоченному их рассматривать судье. В результате сроки давности истекли, и пятеро граждан, совершивших административные правонарушения в области дорожного движения, не были привлечены к установленной законом ответственности[6].

Конечно, перечень обозначенных способов совершения преступлений не является исчерпывающим, но позволяет в определённой мере представить масштабы коррупции в рассматриваемой сфере. Следует обратить внимание, что основная сложность заключается в том, что этот вид преступлений носит латентный характер, то есть скрытый, и без помощи общества их трудно выявить, расследовать и трудно привлечь коррупционеров к ответственности. Главной причиной, затрудняющей работу по выявлению коррупционных преступлений, является необращение граждан в правоохранительные органы. А вместе с тем, криминальные элементы, коррупционированные должностные лица безнаказанно совершают преступления против нашего государства, незаконно обогащаясь за счет добросовестных граждан и удовлетворяют свои иные потребности[12].

В.Л. Римский отмечает, что по частоте дачи взяток ГИБДД уступает только взяткам в больницах, но это объясняется тем, что болеют все граждане и члены их семей, а автомобили имеют не все российские семьи. Среди автомобилистов 44\% давали взятки сотрудникам ГИБДД, причём чаще взятки давали жители крупнейших российских мегаполисов - Москвы и Санкт-Петербурга, высокообразованные и материально обеспеченные.
Поэтому практика решений проблем автомобилистов с ГИБДД стала в последние годы в нашей стране одним из признаков принадлежности к успешным, хорошо образованным и материально обеспеченным социальным группам. Такая социальная особенность взяточничества в ГИБДД существенно осложняет противодействие этому негативному социальному явлению, потому что оно стало привычным для социальных групп, которые меньше других заняты решениями своих материальных проблем и могли бы во взаимоотношениях сГИБДД действовать в общественных интересах, отказываясь от взяток. Но именно для таких социально активных и успешных социальных групп приоритетом во взаимодействиях с ГИБДД является решение собственных проблем, минимизация собственных усилий для их решений. О приоритете противодействия коррупции в общественных интересах они в таких ситуациях не думают[11].

Кроме того, эта проблема оценивается и руководящим составом соответствующих ведомств. В этой связи, к примеру, в 2015 году Владимир Маркин, руководитель управления взаимодействия со средствами массовой информации Следственного комитета Российской Федерации в своём комментарии отметил, что даже, простой просмотр новостей дает понимание того, что чуть ли не ежедневно в разных регионах происходят дорожно-транспортные происшествия, причём с жертвами. И очень часто в этих случаях виновниками аварий становятся водители с минимальными навыками вождения. Среди них наверняка были и получившие права в нарушение установленных для этого правил[2].

Таким образом, существует очевидная необходимость в разработке научно-обоснованной системы рекомендаций, призванных оптимизировать раскрытие, расследование и предупреждение посягательств коррупционной направленности в сфере обеспечения дорожного движения и эксплуатации транспортных средств.

\section{ЛИТЕРАТУРА}

1. Закон Российской Федерации «Федерального закона «0 противодействии коррупции» « от 25.12.2008 №№ 273-Ф3 // Российская газета. 30 декабря 2008 г.г. № 0(4823).

2. Зверкова И. По оценкам экспертов, две трети автомобильных прав в РФ - куплены. URL: http://www.aif.ru/auto/gibdd/42483 (дата 0бращения: 03.05.2021).

3. Конвенция Организации Объединенных Наций против коррупции (принята Генеральной Ассамблеей 00Н 31 октября 2003 г.) (дата обращения: 03.05.2021).

4. Кормление: Википедия. Свободная энциклопедия. URL: https://ru.wikipedia.org/wiki/Кормление (дата обращения: 03.05.2021).

5. Попова Е.И. 0 необходимости комплексного подхода к предупреждению коррупции среди широких слоев населения // Юридический мир. 2018. № 9. - С. 53-55.

6. Приговор № 1-3/11 от 11 июля 2011 г. Морозовский районный суд (Ростовская область).

7. Приговор № 1-102/2016 1-11/2017 от 28 апреля 2017 г. по делу № 1-102/2016 Рыльский районный суд (Курская 0бласть).

8. Апелляционное постановление № 10-1145/2018 от 19 марта 2018 г. по делу № 10-1145/2018 Челябинский областной суд (Челябинская область). 
9. Приговор № 1-102/2019 от 7 мая 2019 г. по делу № 1-102/2019 Соликамский городской суд (Пермский край).

10. Приговор № 1-106/2019 от 28 ноября 2019 г. по делу № 1-106/2019 Приозерский городской суд (Ленинградская область).

11. Римский В.Л. Результаты социологических исследований исполнения государством правоохранительной функции: оценки граждан и необходимые реформы. М., 2012 [Электронный ресурc]. URL: http://www.indem.ru/proi/rpf/ReSolslspGoPF.pdf (дата обращения 12.07.2021).

12. Борьба с коррупцией в России — Общественный Комитет [Электронный ресурс]. URL: http://corrypcii.net (дата 0бращения 14.06.2021).

(с Дарханова Арюна Баировна ( sanaryuna@yandex.ru ).

Журнал «Современная наука: актуальные проблемы теории и практики»

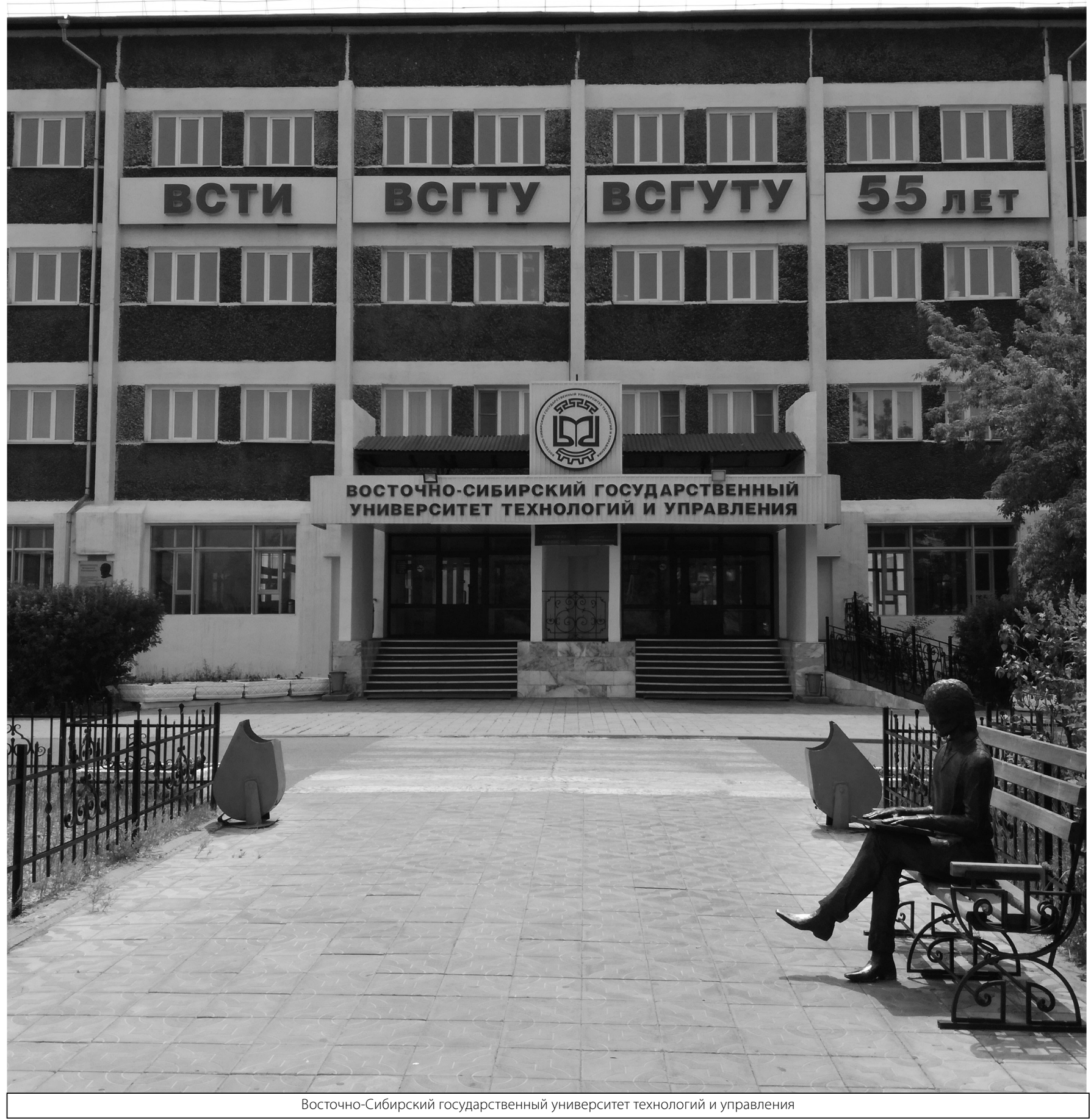

